\title{
BOOK REVIEW ESSAY: A BUMPER CROP OF FAIR TRADE COFFEE BOOKS
}

\author{
John M. Talbot \\ Department of Sociology \\ University of the West Indies \\ john.talbot@uwimona.edu.jm
}

Jaffee, Daniel. 2007. Brewing Justice: Fair Trade Coffee, Sustainability, and Survival. Berkeley: University of California Press. 331 pages. Hard Cover ISBN 978-0520249585, \$ 60.00; Paper ISBN 978-0520249592, \$22.95

Fridell, Gavin. 2007. Fair Trade Coffee: The Prospects and Pitfalls of Market-Driven Social Justice. Toronto: University of Toronto Press. 347 pages. Paper ISBN 978-0802095909, \$29.95

Luetchford, Peter. 2008. Fair Trade and a Global Commodity: Coffee in Costa Rica. London: Pluto Press. 226 pages. Hard Cover ISBN 978-0745326993, \$95.00; Paper ISBN 978$0745326986, \$ 29.95$.

Bacon, Christopher M., V. Ernesto Méndez, Stephen R. Gliessman, David Goodman, and Jonathan A. Fox (eds.). 2008. Confronting the Coffee Crisis: Fair Trade, Sustainable Livelihoods, and Ecosystems in Mexico and Central America. Cambridge: Massachusetts Institute of Technology Press. 390 pages. Hard Cover ISBN 978-0262026338, \$67.00; Paper ISBN 9780262524803, \$27.00.

The history of the world coffee market is a story of cycles of boom and bust. The most recent bust, one of the most severe in history, began in 1998 and started to ease in 2005. This period of severe crisis across the coffee producing countries in the developing world stimulated a growing interest in fair trade coffee as a means of helping the small farmers who were being devastated by historically low prices. As public interest and consumption grew, social scientists, as is their wont, set out to study the phenomenon. The result is the current bumper crop of books analyzing fair trade coffee.

This review covers four books published in 2007 and 2008, based on research that spans the period of the crisis. Do we really need four books on fair trade coffee? I will argue that we do. Of course, the reader may want to take this assertion with the proverbial grain of salt, because I am fascinated by all things relating to coffee. However, these books have complementary strengths and weaknesses; each of them takes its own distinctive approach to the subject, adding layers to the analysis that are missed, or addressed only in passing, by the others. By combining all four, we can derive a more comprehensive picture of the multi-faceted phenomenon that is fair trade coffee.

If you only have time to read one book, I would recommend Jaffee's; this is a very well done analysis that centers on fair trade producers, but also gives thorough consideration to the dilemmas faced by fair trade in the consuming markets. The extensive methodological appendix also adds value for use in graduate courses. However, Jaffee's is a "conventional” analysis of Fair 
Trade, one that is empirically focused on elucidating its benefits to producers and the opportunities and dangers that arise from its rapid expansion and mainstreaming. Fridell's book provides a broader theoretical framework within which to situate the analysis. The framework has some problems, but the effort is commendable nonetheless. If we are going to resolve the many dilemmas facing fair trade today, more theoretically-driven work is necessary. Luetchford's book has the most ethnographic depth, taking us inside the world of peasant producers to show how they view the market and why fair trade is a problematic concept for them. However, he does not use this insight to address questions regarding the future of fair trade. Finally, the book edited by Bacon, et al. adds a focus on the environmental aspects of fair trade production, most of which is also organic. In addition, portions of this book take an action research approach to explore ways of moving beyond fair trade in the transformation of international economic relations. However, as an edited volume, it is somewhat uneven in quality and not as tightly integrated as the other books.

Fair trade grew out of the initiatives of alternative trading organizations (ATOs) based in Europe in the 1960s and 1970s. These ATOs, many religiously based, attempted to counteract the unfair trade rules of the global economy by importing handicrafts directly from small cooperatives in their countries' former colonies, selling them in designated "world shops" at high prices, and returning most of the proceeds to the direct producers. Coffee was the first food product marketed by the ATOs, but since the sales volume was low, the benefits to coffee producers were small. In 1988, the Solidaridad ATO in the Netherlands and the UCIRI ${ }^{1}$ cooperative in Mexico created the modern fair trade system based on certification. Mainstream coffee roasting companies that agreed to purchase a certain amount of green coffee at a fixed, higher price from the cooperative then had the right to affix a seal (the Max Havelaar ${ }^{2}$ label) to an equivalent amount of their roasted coffee sold in supermarkets. The consumer could choose to pay a higher price for this coffee, secure in the knowledge that the price difference was being returned to the producers. This greatly expanded the volumes of coffee that could be sold and the benefits that could be returned to producers, but also brought in as key players a group of large corporations that had no interest in changing the rules of global trade in any fundamental way. This created the contradiction that has plagued fair trade coffee ever since, that it operates simultaneously "in and against the market" (Barratt Brown 1993, 156). And, despite this compromise, because of the higher prices paid for fair trade green coffee, the supply has far outstripped the demand, so that many fair trade cooperatives can sell only a small percentage of their production through fair trade, and must sell the rest at lower prices on the conventional market.

Jaffee explains the rationale for his study: "Supporters of fair trade make some impressive claims about the benefits it generates. ... I set out to examine these claims and to find out how peasant coffee producers are actually experiencing fair trade.” (3) To do this, he conducted fieldwork and collected survey data in two communities where some coffee growers

\footnotetext{
${ }^{1}$ Unión de Comunidades Indígenas de la Región del Istmo in Oaxaca.

${ }^{2}$ Taken from the title of the classic anti-colonial novel, Max Havelaar, or the Coffee Auctions of the Dutch Trading Company, written by Eduard Douwes Dekker, under the pseudonym Multatuli and published in 1860. The novel exposed the brutality of the system under which coffee was produced for the Dutch East Indies Company in Java.
} 
were members of the Michiza ${ }^{3}$ cooperative, in Oaxaca, Mexico. The fact that some growers in these villages belonged to the coop and sold their coffee through fair trade, while others were not members and sold to the conventional market, allowed him to collect comparative survey data on the two groups to measure the benefits of participation in fair trade. The Michiza coop was also somewhat unusual in that it sold all of its exports (80\% of total production) to the European fair trade market, but this enabled him to capture the full extent of the fair trade benefits.

Jaffee finds that fair trade does provide benefits to producers and to the villages as a whole, but the picture is much more complex and nuanced than the promoters of fair trade claim. Fair trade producers did receive higher prices for their coffee than the conventional producers, but they also had higher production costs, mainly because they produced organic coffee. Although the higher prices were due primarily to Michiza's connection to the fair trade market, the producers identified as organic producers, because this was what impacted their daily routines. Many of the producers Jaffee spoke to consequently had only a vague idea what fair trade was. After conversion to organic production, which itself is very costly, the major additional production expense was labor, for pruning, weeding, building terraces and live barriers, and spreading compost, all required to maintain organic certification. However, the coffee crisis sparked a wave of emigration from the villages, making day laborers scarcer and raising the price of this additional labor. Jaffee found that many of these laborers came from conventional producer households, and thus the some of the higher prices received by Michiza members were actually cycled to conventional households through the labor market. Despite all of this, and indicating the precarious position of peasant producers in the global economy, most families he surveyed had negative net incomes; the Michiza members were just losing slightly less.

Michiza members received several payments for their coffee from the coop that were spread over time, while the conventional producers were paid once when they sold their coffee. So coop members tended to have cash available to them in the off-harvest seasons, and they also had access to no-interest loans for emergencies; therefore, they were less likely to fall into a cycle of debt with local usurers. This greater economic stability tended to keep coop member households on the land, while paradoxically encouraging emigration by household members. Some of this emigration was to attend postsecondary schools in the cities, and some was to earn money to pay for the additional labor required to sustain their organic coffee production. The conventional households, while less likely to have household members emigrate, were more likely to emigrate as whole families, probably for good. The greater stability of coop members also meant that they had somewhat better housing conditions, slightly more consumer goods (e.g., televisions), and that they were more food secure and had better, more varied diets. Jaffee also considers the environmental aspects of fair trade/organic production. While most peasant production is passively organic (that is, no chemicals are used), certified production is actively organic (that is, labor intensive practices and organic compost applications are used to raise productivity). He finds that these active organic practices have demonstration effects; some of them are being taken up by conventional producers, and some are also being extended to the milpas, the plots where households grow their subsistence food crops. In brief, fair trade does provide numerous benefits to small coffee growers, and not only to those who belong to fair trade coops, but some of the claims of fair trade promoters are simplistic or exaggerated.

\footnotetext{
${ }^{3}$ The name comes from the first letters of the different indigenous groups that belonged to the coop when it formed: Mixes, Chinantecos, and Zapotecos. Jaffee's research was conducted in two Zapoteco villages.
} 
The four chapters where this analysis of the benefits to producers is presented is the heart of Jaffee's book. But he adds two chapters analyzing the dilemmas facing fair trade in the consuming markets. Here, there is a fissure between the "100 percenters," companies that sell only fair trade coffee, and the larger corporations like Starbucks for whom fair trade represents only a tiny proportion of their total sales. The latter get involved in fair trade mainly under activist pressure and as a means of "image laundering" (210), but generally do not support the larger goals of fair trade. He outlines some of the corporate strategies against fair trade: participate, but ensure that it remains a niche market; compete against it with self-policed corporate codes of conduct; switch to a competing "sustainable" certification with lower social standards (e.g., Rainforest Alliance); promote the certification of plantations, which will squeeze out many small producers; and try to weaken the standards and lower the guaranteed minimum price (which has been raised only once, slightly, since 1988). Another important issue is the balance of power between the northern certifying organizations, which have almost complete power to set and change the standards southern producers must meet, and the cooperatives that actually produce the coffee. He argues that consumers, if they are really concerned about the welfare of southern producers, have a moral obligation to address this imbalance and to find ways to increase the benefits of fair trade, by helping producer coops to gain a share of ownership in the companies selling their products in the consuming markets. He advances a number of other recommendations for making fair trade fairer; ultimately it comes down to whether fair traders' long term goal is simply to increase market share or to fundamentally transform international trade.

Fridell's book provides two contrasts with Jaffee's: it is much more focused on the macro-structures of fair trade within the global market, and it is much more theoretically based. As discussed above, Jaffee's main research questions emerge from the claims of fair trade supporters - he sets out to test their validity. Fridell, on the other hand, begins by situating fair trade (what he calls the fair trade network) within a larger fair trade movement which attempted to change the rules governing the international economy. This movement included international commodity agreements, ECLA development policies, attempts to create corporate codes of conduct, and the call for a New International Economic Order. He follows Colin Leys, Robert Brenner, and others in arguing that this movement was informed by underdevelopment and dependency theory (UDT), a category which lumps together Latin American structuralism, dependency theories, and world-systems analysis. World-systemites will find this aspect of the book annoying, as they will interpret his repeated characterization of UDT as neo-Smithian. But the larger point has some validity - these efforts relied on trade reform and state interventionism to overcome the unequal structures of the world economy, giving much less attention to the effects of class structures within Third World countries (and I might add, overlooking the many excellent and detailed analyses of these class structures that had been carried out by dependency theorists). The argument that fair trade was part of this larger movement is not completely convincing, because it never really focused on state intervention, except in the work of Michael Barratt Brown (1993), whom he cites extensively.

The fair trade movement flourished during the period of embedded liberalism, from the 1940s through the 1970s. This was the period of the ATOs in the fair trade network. The movement died out under neoliberalism, but the fair trade network was reborn as the fair trade certification system, a neo-Smithian accommodation with neoliberalism: 
While frequently depicted as being in direct opposition to neoliberal globalization, the fair trade network in its current form in fact represents a neoliberal version of its earlier model and has been adopted by many international organizations and conventional corporations as a neoliberal alternative to the other, statist projects of the fair trade movement. Thus, it is the fair trade network's relative compatibility with neoliberal reforms that has been key to its rapid growth over the past decade and a half. (51, italics in original)

Thus the ATOs may not have been a part of the fair trade movement, but the invention of the certification system made the fair trade network into its acceptable successor. Other analysts have observed that fair trade and other certification systems are symptomatic of the shift from public to private regulation under neoliberalsim (e.g., Raynolds and Wilkinson, 2007), but Fridell puts a sharper point on this observation.

Fridell also presents a useful analysis of the current literature on fair trade, dividing it into three types. First there is the shaped advantage perspective, which sees fair trade as an effort to help disadvantaged southern producers compete effectively in the global market. This perspective points out that the structure of the global market limits the demand for fair trade coffee and the level of the minimum guaranteed price, but tends to take globalization as an inevitable force that must be accommodated with. The strengths and weaknesses of this approach are elaborated through a case study of the UCIRI fair trade coop in Mexico. The alternative globalization perspective sees fair trade as an attempt to create an alternative to the neoliberal trading system, but fails to understand that fair trade represents an accommodation with neoliberalism. The decommodification perspective sees fair trade as an attempt to overcome the fetishism of commodities under capitalism, but Fridell questions whether it actually intensifies fetishism, as it "becomes possible to purchase ethics at the local supermarket" (97). These three perspectives in the literature parallel Jaffee's characterization of three different views held by fair trade participants: fair trade as market access, as market reform, and as market transformation.

Fridell pursues his point about commodity fetishism through a comparative analysis between two coffee roasting companies at the opposite ends of the scale of fair trade sellers - the Planet Bean cooperative in Guelph, Ontario and Starbucks. "To Planet Bean, fair trade is a movement that aims to attain social justice in the South and the North" (245), so it is moving toward worker ownership and democratic control. It puts considerable effort into educating consumers about the people who produce the coffee, forms relationships with southern producer groups, and brings representatives to the north to meet the consumers. This creates bonds of solidarity between producers and consumers, and makes consumers aware that their purchasing decisions have impacts on many other people, thus breaking down commodity fetishism. Starbucks, on the other hand (need I say more?) is anti-union, although it does provide better pay and benefits than most food-service employers. It combines two of the corporate strategies outlined by Jaffee: it tolerates fair trade only because of activist pressure but does not make much effort to promote it and expand its sales, and it prefers its own "corporate social responsibility" programs to participation in fair trade. Put simply, democratic control of any aspect of its business is anathema to Starbucks. Although Fridell does not make this point, I would add that Starbucks uses depictions of exotic producers in exotic tropical locations to add cachet to the commodified coffee it sells (Smith, 1996). This is the height of fetishism. 
Fridell concludes by arguing for fair trade as a moral economy, a term which is hardly mentioned in the rest of the book. He refers to the pre-capitalist "moral economy of provision" described by E. P. Thompson among the English peasantry at the start of the Industrial Revolution, which has similarities to the moral economy of contemporary peasant coffee producers. It is ironic that he makes only a few recommendations at the very end of the book, because his work provides a sounder theoretical foundation for a number of the recommendations laid out by Jaffee: addressing the north-south power imbalance by giving southern producers equal voice in the umbrella standard-setting and certification organizations and ownership shares in northern fair trade businesses; setting (and enforcing!) standards for minimum percentages of fair trade coffee that must be purchased by all roasting companies wishing to participate; creating a label to differentiate between companies selling $100 \%$ fair trade and those selling the minimum percentage; and forging stronger linkages with the global justice movement.

Peter Luetchford takes us to the opposite end of the scale of analysis, with a microfocused ethnography of a small coffee-producing village in northwest Costa Rica. The concepts of a moral economy and commodity fetishism are central to this analysis. According to Luetchford, the world view of Costa Rican peasants is shaped by Catholic social thought as well as ideas of the national identity based on the autonomous, small, family farm. Nature is viewed as a force that brings forth a variety of living things, including food. "Some foods, mainly fruits such as mangoes, oranges, bananas, and avocados, seem to produce themselves, and grow in such abundance that they are considered open to access for all or are freely distributed and even squandered." (144) However, nature is unpredictable and does not freely provide everything that humans need. Therefore, humans must struggle in nature and with nature in order to coax it to produce all of the things needed to support their families. Another major category of products are thus those that are produced through this struggle for household consumption ("por el gasto"), including maize and beans, root crops, and vegetables. Then there are the crops that are produced for sale on the market, such as coffee.

Within this economy, production for subsistence is most highly valued. There are many informal exchanges between community members, but they do not operate on a market logic:

Things often move in personalized exchanges between producers and consumers, ... there is a formal reckoning of monetary worth, but prices and terms vary according to ability to pay ... Finally, things are frequently given away or lent without any apparent or explicit expectation of recompense. (125)

Luetchford uses Mauss's concept of the gift to explain these exchanges as creating affective ties between people and establishing norms of reciprocity. People are also entitled to sell anything that they have produced on the market, but this is understood as a distinct type of transaction.

Luetchford analyzes the language people use to talk about the market: "Four terms are used; each is linked to a common set of ideas, related to the idea of a game, and oriented to the notion of uncertainty. They are: jugar (to play); jugarse (to juggle or gamble); la loteria or la rifa (lottery or raffle); and tantear (to try to calculate or size up).” (56) This language emphasizes the uncertainties and risks involved in producing for the market. One might think that a particular crop will bring a good return, but there may be too much rain, or too little, or many other producers may bring the same crop to market at the same time, causing the price to crash. Peasants thus never put all of their eggs into one basket; they play with this or that crop, juggle 
several crops, take a chance on a new crop, all the while seeking out information that will allow them to size up their chances in the game. This is why they have difficulty with the concept of fair trade - they do not expect the market to be fair. They seek justice and fairness in their informal exchanges, but the market is always a game of chance. This analysis goes deeper than Jaffee's and suggests a more fundamental reason why producers may have only a vague idea about what fair trade is. It is not that they conflate organic production with fair trade, but that fair trade is an oxymoron within their world view.

Luetchford argues that peasants operate with an implicit labor theory of value. Value is created through the struggle with nature to produce things. Trade, on the other hand, involves the appropriation of some of that value by people who do no real work. He relates a parable told by one of his informants about a man who produces some peppers and takes a bag of them to the merchant. The merchant pays him and tells him to set the bag in the corner. A buyer comes along, the merchant sells him the bag of peppers for twice what he had paid for it, and the buyer picks up the bag and carries it away. The merchant has made as much money as the man who produced the peppers, but he did not even touch the peppers! Thus when a producer sells what he has produced, he deserves to earn whatever he can get for it on the market. But any money earned from trading is suspect. Luetchford uses this aspect of the peasants' world view to explain their distrust of the fair trade coop. The coop deducts money from what it earns by selling their coffee; this looks suspiciously like earning money by trading rather than producing. With this money it employs about 30 people to run the coop. These people are "lazy" according to the producers, because they do not engage in the struggle with nature that constitutes real work. Further, they are paid a guaranteed salary every week, while the producers are never certain whether their gambles in the market will pay off at all. Again, the analysis goes deeper than Jaffee's. He relates a meeting of the Michiza coop where producers question the amounts deducted by the coop for administrative costs, but takes the perspective of the coop management that the questions originates in a lack of understanding of how much it costs to run the coop. All that management needs to do from this perspective is to show that all money deducted has been responsibly spent. But from the perspective of Luetchford's peasants, this explanation completely misses the point of the objections.

Luetchford argues that Western consumers share elements of this anti-capitalist moral economy with the peasant producers. They long to establish personal connections with the people who produce the things they consume. This explains the popularity of farmers' markets and other direct distribution channels, as well as the popularity of fair trade. Fair trade consumers, he argues, are giving a gift to producers by paying a higher price. In this way, they seek to establish personal connections with producers as well as support a lifestyle where people still produce primarily for use value. All of this recalls Fridell's discussion of moral economy, but Luetchford's discussion is much more detailed and extensive. However, Fridell might insert a cautionary note here that, while this may be true for consumers who purchase from small 100percent fair trade roasters, the typical Starbucks consumer may be an upper middle class person displaying their class distinction. Luetchford would reply that we need to take seriously "what consumers like to think they are doing when buying fair trade goods" (181), and recognize that there is a political backlash against the myriad negative impacts of commodity fetishism that are becoming more apparent every day. While Fridell presents a sounder theoretical basis for Jaffee's recommendations, Luetchford here presents a sounder moral and philosophical basis. However, 
Luetchford does not use his insights about shared moral economies to recommend ways to improve fair trade. He seeks only to explain the popularity of fair trade and stops there.

For ideas about how to build shared moral economies, we must turn to the work of Christopher Bacon and his colleagues in Mexico and Central America. For me, the highlight of this edited volume was the penultimate chapter by Jaffe and Bacon, describing the work of the Community Agroecology Network (CAN), started by a group of researchers at the University of California, Santa Cruz (mainly the co-editors of this volume) in conjunction with five coffeegrowing communities in Veracruz and Yucatan Mexico, Nicaragua, El Salvador, and Costa Rica. This participatory action research (PAR) project attempts to go beyond fair trade by returning to its roots in alternative trading networks. "Our goal is to build relationships between farmers and consumers so that the coffee drinker understands the individuals and the ecosystems that produce the coffee, and farmers learn about the people drinking their coffee.” (319) A major component of this work is educating coffee farmers about the US coffee market, and about what qualities in the coffee are considered most desirable. Then the farmers can work to improve their production and processing in order to achieve these qualities. They have also worked to establish direct marketing channels into the US market, so that the farmers' cooperatives can retain more of the profit than is possible through fair trade. These increased profits are used to enhance the sustainability of their production and increase biodiversity in their communities, including the development of ecotourism projects. An internship program has also been developed to send US students to work in these communities for a semester. "Farmers often talk about how they had never really valued their role as a farmer before and how they see that they have a lot to share with young people" (322) ${ }^{4}$ This seems to be the kind of project needed to build a shared anticapitalist (or at least, post-capitalist) moral economy between producers and consumers, that Luetchford only hints at.

This book is also somewhat broader than the others considered here, because it is not focused exclusively on fair trade coffee. Instead, it analyzes a variety of responses to the coffee crisis, including recourse to fair trade, organic production, and shade production. The book starts with an introductory section providing background. Goodman's essay sets the coffee crisis in the context of the turn to neoliberalism in the 1980s, and sets the rise of specialty, fair trade and sustainable coffees in the context of the turn to quality in consumption that accompanied it. He discusses the main issues raised by the mainstreaming of fair trade coffee. Gliessman introduces the agroecology framework used in the analyses of the environmental aspects of coffee production in the book. Petchers and Harris, two Oxfam researchers, present an overview of how the coffee commodity chain has been restructured since the end of the International Coffee Agreement (ICA) in 1989. Although occasionally superficial and simplistic in its analysis, it provides a good picture of the many disadvantages facing the small coffee grower in the TNCdominated chain.

The next section of the book focuses on the agroecological dimension. Some of the research reported here comes from the communities in the CAN, but there is additional research from Chiapas and Nicaragua as well. Some of this research was done in the late 1990s or early

\footnotetext{
${ }^{4}$ More details on this project can be found at their web site, http://www.communityagroecology.net/. Coffee can also be ordered directly from the coop in Costa Rica at this site. It may take a while to arrive, but it is very good.
} 
2000s and does not really address farmers' responses to the crisis; other research narrows the broad agroecology focus down to one indicator: tree species diversity. Notable in this section are two articles that provide historical overviews of the evolution of the agroecology of coffee production, by Trujillo for Veracruz and Westphal for Nicaragua. Trujillo develops a typology of eight different production strategies involving coffee, subsistence production, and other incomegenerating activities, that can be identified in central Veracruz today. She shows how they depend on the topology of the region, degree of integration into markets, and the changing national regimes governing coffee production. Under the ICA production regime, the national coffee agency promoted green-revolution-style production of high-yield varieties in monocultures. After the ICA ended, the coffee agency was abolished, and farmers were left on their own. The current variety of strategies evolved, with many of the monocrop producers turning to multicrop strategies, usually involving more shade production. A somewhat similar story emerges from Nicaragua, where the Sandinistas in the 1980s attempted to collectivize existing coffee plantations, also using the green revolution model. This effort was abandoned after the Sandinistas lost power in 1990, and the plantations were divided up into individual plots and distributed to the collective members. These new small farmers converted rapidly to a multi-crop, shade-grown coffee production strategy that tended to have even higher biodiversity than small farms that had remained privately-held and outside the collective system under the Sandinistas. This was done as a means of reducing costs by minimizing use of chemical inputs, diversifying output in order to spread risks and provide a steady income, and providing for their own subsistence. It seems that at least in some regions, the coffee crisis has exposed the unsustainability of technified coffee production and forced some farmers to turn to more sustainable methods.

The third section of the book focuses on the growth of fair trade, organic, and other "sustainable" forms of coffee production as responses to the crisis. Bray et al. analyze the spread of organic coffee production in Mexico, and specifically in Chiapas. They argue that organic production was not primarily a response to the availability of price premiums in northern markets; rather, it was an outcome of organizing efforts by small farmers trying to cope with the collapse of prices and disappearance of the national coffee agency after the end of the ICA. Their case study of a producer coop in Chiapas shows that organic production also provides a range of benefits to coffee growing communities that go well beyond the price premium, such as environmental improvements and increased yields of associated crops such as fruit trees, social benefits offered through the cooperative, and ownership of a small chain of coffee houses within Mexico. Echoing Jaffee, they note that organic techniques are spreading from the coffee plots to the milpas, and highlight this as a priority for further efforts that could produce major environmental benefits.

Another excellent article in this section is Mutersbaugh's analysis of how organic certifications are actually conducted on the ground in Oaxaca. In a contrast reminiscent of Luetchford's between the moral economy of the peasant and the rationality of the market, Mutersbaugh contrasts the indigenous tradition of unpaid community service work with the technical objectivity of the certification system. The inspectors who carry out organic inspections are surveillance agents of the certifying agencies. They are there primarily to gather information and report back; they are allowed to point out deficiencies to the farmers, but they are not allowed to tell them how to remedy those deficiencies. This would compromise their objectivity. The training and extension functions are to be provided separately through the producer coops 
(community service). The way this contradiction is finessed on the ground is by having people trained in both functions who operate in teams. The person serving as inspector, inspecting villages outside his own in order to remain objective, is paired with a person from the local community wearing her "extension worker hat," who is thereby allowed to "translate" the culture of the inspection into the local culture, and suggest to the farmer being inspected how to remedy any deficiencies found.

This section also includes the article by Jaffe and Bacon discussed above. Another article discusses some of the proliferating certifications for coffee: fair trade, organic, Rainforest Alliance and Utz Kapeh. However, it takes corporate propaganda at face value, and misses the points made by Jaffee about corporate strategies to evade or weaken the more rigorous standards of fair trade. The section and the book conclude with an excellent chapter by Bacon, Méndez and Fox. While the contributions to the volume are disparate and uneven in quality, this chapter does a good job of pulling all of the issues and themes they raise together into a coherent overview of responses to the crisis. It also includes an extended reflection on the future of fair trade, which puts many of the recommendations made by Jaffee and Fridell into a broader context. The authors identify two central paradoxes of fair trade. One is the power imbalance between north and south, and the other is the tension between size and values: has fair trade coffee become a movement "that sells out in order to scale up"? (361) The unequal distribution of power between north and south has constructed a global coffee commodity chain that creates wealth for the northern TNCs and poverty for southern producers. But it has also constructed the fair trade system that purports to help the impoverished southern producers. The legacy of this power imbalance is seen in the unequal distribution of power within the Fairtrade Labeling Organization (FLO), the global standard-setter, where southern producers have struggled to achieve representation amounting to four of the twelve seats on the Board of Directors. It is seen in the fact that the costs of the transition to organic production and of continuing organic certification are borne by southern producers, and in the fact that the costs of fair trade certification have recently been shifted from companies selling fair trade coffee to the producers. It is seen in the fact that complete transparency is required of southern producers, while FLO refuses to release information on the percentages of companies' total coffee sales that are fair trade. This last point also highlights the tension between size and values. FLO has prioritized increasing the size of the market, while compromising on all of the values of the non-capitalist moral economy that motivated the creation of fair trade in the first place. In order to entice TNCs into fair trade and grow the market, it has agreed not to reveal any of their "trade secrets," thereby sacrificing the value of transparency. The conflict between size and values also reveals a potential problem of the CAN project described above. It may help a few small producer coops to increase their living standards, but can it be scaled up without losing sight of the personal connections and moral economies on which it was built?

I have argued that each of these books makes a significant contribution to our understanding of fair trade coffee, and by extension the entire fair trade system. There are obvious commonalities and overlaps among the four in the aspects of fair trade examined and the arguments advanced. Yet each takes its own unique perspective, creating many synergies between them. There is a general sense, among participants in the fair trade system as well as among the social scientists who study it, that fair trade has reached a crossroads and some fundamental decisions must be made. This set of books helps us to see the outlines of what is at stake and what the implications of some decisions could be. But it also makes clear that too much of the work on 


\section{JOURNAL OF WORLD-SYSTEMS RESEARCH}

fair trade so far has been narrowly empirically focused, and that resolution of the current dilemmas requires more theoretical and philosophical work. These books start us in that direction, but more is needed. Thus having started by arguing that we really need four books on fair trade coffee, I conclude by arguing that we need even more.

\section{References}

Barratt Brown, Michael. 1993. Fair Trade: Reform and Realities in the International Trading System. London: Zed Books.

Raynolds, Laura, and John Wilkinson. 2007. "Fair Trade in the Agriculture and Food Sector: Analytical Dimensions,” in Laura Raynolds, Douglas Murray and John Wilkinson (eds.) Fair Trade: The Challenges of Transforming Globalization. New York: Routledge.

Smith, Michael D. 1996. "The Empire Filters Back: Production, Consumption, and the Politics of Starbucks Coffee.” Urban Geography 17:502-24. 